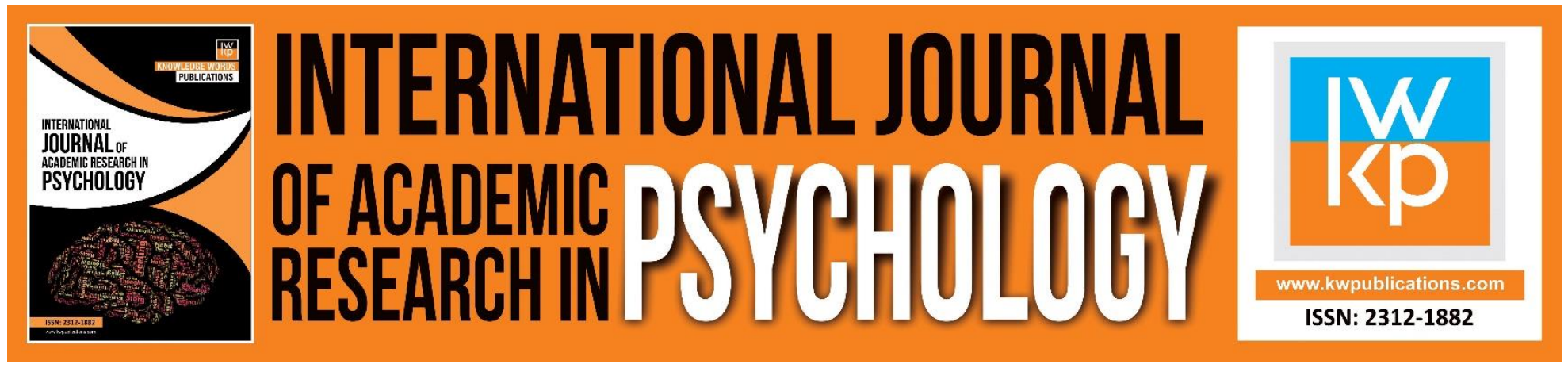

\title{
Effect of Yogic Interventions on the Physical Fitness in Terms of Flexibility and Stamina (Cardio-Vascular Endurance) and its Resultant Effect on the Academic Achievement of High School Students
}

Anita Sharma, Rakesh Parihar

To Link this Article: http://dx.doi.org/10.46886/IJARP/v5-i1/2493

DOI:10.46886/IJARP/v5-i1/2493

Received: 17 October 2018, Revised: 23 November 2018, Accepted: 19 December 2018

Published Online: 29 December 2018

In-Text Citation: (Sharma, \& Parihar, 2018)

To Cite this Article: Sharma, A., Parihar, R. (2018). Effect of Yogic Interventions on the Physical Fitness in Terms of Flexibility and Stamina (Cardio-Vascular Endurance) and its Resultant Effect on the Academic Achievement of High School Students. International Journal of Academic Research in Psychology. 5(1), 40-53.

Copyright: (c) 2018 The Author(s)

Published by Knowledge Words Publications (www.kwpublications.com)

This article is published under the Creative Commons Attribution (CC BY 4.0) license. Anyone may reproduce, distribute, translate and create derivative works of this article (for both commercial and non-commercial purposes), subject to full attribution to the original publication and authors. The full terms of this license may be seen

at: http://creativecommons.org/licences/by/4.0/legalcode

Vol. 5, No. 1, 2018, Pg. 40 - 53

https://kwpublications.com/journals/journaldetail/IJARP

JOURNAL HOMEPAGE

Full Terms \& Conditions of access and use can be found at https://kwpublications.com/pages/detail/publication-ethics 


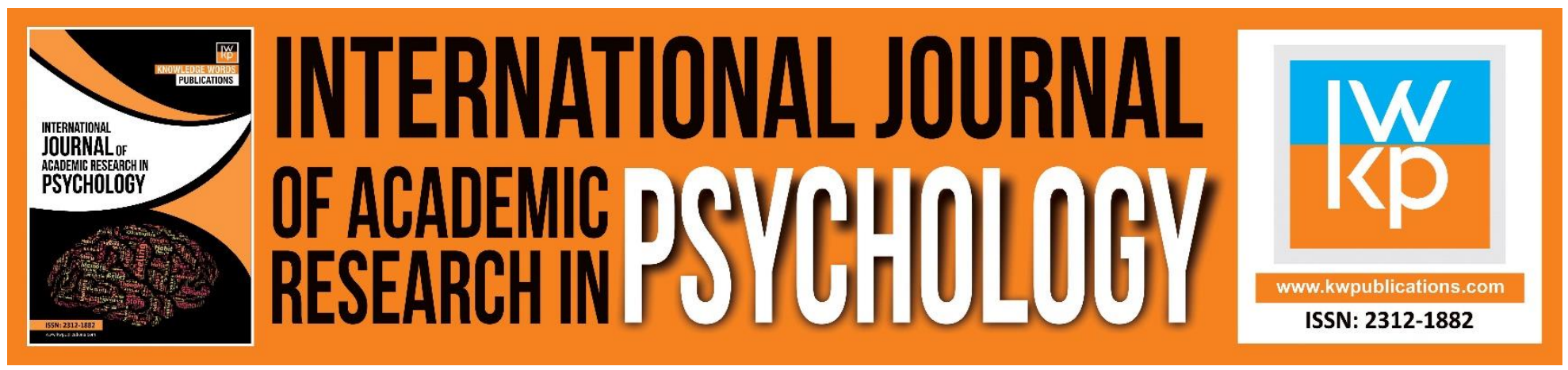

\title{
Effect of Yogic Interventions on the Physical Fitness in Terms of Flexibility and Stamina (Cardio-Vascular Endurance) and its Resultant Effect on the Academic Achievement of High School Students
}

\author{
Dr. Anita Sharma \\ Associate Professor, Department of Psychology, and Deputy Director, UGC, HRDC, Himachal \\ Pradesh University, Shimla, India. \\ Rakesh Parihar \\ Clinical Psychologist, Lahual Spiti, Himachal Pradesh, India.
}

\begin{abstract}
The gamut of the present experimental research was to examine the effects of yogic exercises on the physical fitness in terms of flexibility and endurance and their resultant effects on the academic achievement of high school students. A representative sample of 200 students (100 males and 100 females) of high school level was drawn randomly from two high schools and were further divided into two groups i.e., experimental and control group each consisting of equal number of males and females. Yogic exercises were given to the experimental group for a period of three months. The control group was not exposed to the yogic training. A factorial design of $2 \times 2 \times(2)$ with repeated measure on the last factor was employed to see the significance of difference between different means of experimental and control group in both the genders. Results indicated that flexibility and endurance was improved significantly and thereby improved the academic performance of the students significantly for the experimental group irrespective of gender. The study has important implications for school students for employing yogic exercises in their school curriculum.
\end{abstract}

Keywords: Yogic Interventions, Fitness, Flexibility.

\section{Introduction}

Yoga is one of the six orthodox Indian philosophies. Its philosophical and metaphysical aspects may be accepted, or denied but there is no doubt about its rewards in the form of better health, vitality and psycho-physical poise. Yoga has now been recognized not only as a routine practice for 
general well-being, but also a therapeutic agent for certain diseases. Yoga is traditionally recognized as a spiritual system in which the interdependence of mind and body is emphasized.

The problem school students facing today are lack of concentration in the their studies, poor eye hand co-ordination, poor information processing skills and poor physical health, which results ultimately to poor scholastic achievement. Yoga culture is the dire necessity for bringing psychophysiological equilibrium aiming to achieve positive physical and mental health. Yogic philosophy has always believed in the integration of body and mind.

The present study was conducted to observe the effect of yogic exercises on the physical fitness and academic achievement of high school students. First of all, to achieve these objectives, students of standard's -8th, 9th and 10th from two high schools of district Solan in Himachal Pradesh were selected. A representative sample of 200 students, comprising of 100 male and 100 females were randomly selected. They were further divided into an experimental and a control group respectively. Yogic exercises were given to experimental group.

Three variables were taken into account for the present Study (I) flexibility, (2) Stamina in terms of cardio-vascular endurance and (3) academic achievement. Then the selected sample was assessed on selected variables. Their academic achievement score was taken from school records. A pre and post study was done to see the effect on selected variables.

Many modern scientists have recognized the fruitfulness of research efforts in the field of yoga especially for the school students. Asanas and pranayama key practices in yoga emphasize relaxation of body and mind and bring the psycho-physiological equilibrium. Asanas work on tone and equilibrium at physical level and one experiences stability, comfort, ease and promotion of health and fitness. Asanas are claimed to give rise to develop stability, steadiness and lightness of the body.

Pranayama have beneficiary effect on cardio-pulmonary efficiency as oxygen consumption, carbon dioxide output ventilation and oxygen content have been affected for better functioning. The practice of asana and pranayama prepare background for psycho-physiological fitness. The word "Yoga" comes from the Sanskrit root 'yuj' which means "to yoke" or "to unite", common meanings include "joining" or "uniting", and related ideas such as 'union' and "conjunction" (Apte, 1965). In the spiritual sense, yoga means union of the mind with the divine intelligence of the universe. Yoga aims through its practice to liberate a human being from the conflicts of duality (body-mind), which exists in every living thing (lyengar, 2004). One of the yoga practices, Hatha Yoga, is based on the knowledge, development and balance of psycho-physical energies in the body and can, therefore, be referred to as the "psycho-physical yoga" (James, 2002).

In Indian philosophy, Yoga is the name of one of six orthodox philosophical schools (Radhakrisnan, 1967). The sage Patanjali is regarded as the founder of the formal Yoga philosophy. Many Hindu texts discuss the aspects of Yoga and praising it to enhance the good health and prosperity including, the Vedas, the Upanishads, the Bhagavad Gita, the Yoga Sutras of Patanjali, the Hatha Yoga Pradipika, the Shiva Samhita and the Gherand Samhita (Chatterjee et al., 1984). Major branches of yoga include: Hatha Yoga, Karma Yoga, Jnana Yoga, Bhakti Yoga and the Raja Yoga (Swami Ram, 2008). Through desireless action in the world, one can attain moksha, the supreme goal of life. Yoga is the state of equilibrium of body, mind and intellect. 


\section{Yoga in Vedas}

When all the five senses with mind are dissolved in soul then that state is called yoga. The sage Patanjali is regarded as the founder of the Yoga Sutra. Patanjali's yoga is known as Raj yoga, Patanjali defines the word "Yoga" in his second sutra, which is the definitional sutra for his entire work.

Declined health and fitness status among school children is a significant clinical and social problem. The problems that school students are facing today are lack of concentration in their studies, poor information processing skills and poor physical health, which results ultimately to lower scholastic achievement. Many recent investigations indicate increased trend of severity of health problems more so in terms of fitness among school children that affect their overall working capacity. Thus, it becomes necessary to enhance the cognitive functioning, information processing skills and health related physical fitness of high school students. This enhancement would then lead to an improvement in academic achievement.

Yoga culture is the dire necessity for bringing psycho-physiological equilibrium aiming to achieve positive physical and mental health. Considering the above facts, the investigators intended to find out whether training in yoga would help to improve the specified physiological functions like flexibility and stamina in terms of cardio-respiratory endurance, which are prerequisites for a healthy mind.

In this era, students generally complain of lack of concentration in studies resulting in underachievement. The reason behind this is the distorted and scattered attention leading to poor concentration and poor academic achievement. So, the present endeavour has been designed to observe the effect of yogic practices such as asanas, pranayama, meditation, Om chanting and tratka in the enhancement of flexibility, stamina and academic achievement of students.

Keeping these facts in mind the present study has following aims and hypotheses:

\section{Aims}

$>$ To assess the effect of yogic exercises on the flexibility of high school students.

$>$ To assess the effect of yogic exercises on the stamina (cardio-vascular endurance) of high school students.

$>$ To assess the effect of yogic exercises on the academic achievement of high school students.

\section{Hypotheses}

$>$ Yogic exercises will enhance the flexibility of high school students.

$>$ Yogic exercises will enhance the cardio-respiratory endurance of high school students.

$>$ Yogic exercises will enhance the academic achievement of high school students.

\section{Methodology}

A factorial design $2 \times 2 \times(2)$ with repeated measure on the last factor was employed for the present study. A representative sample of 200 students was divided into two groups i.e., experimental and control each consisting of equal number of males and females. Yogic exercises were given to the experimental group for a period of three months. The control group was not exposed to yogic training. 
INTERNATIONAL JOURNAL OF ACADEMIC RESEARCH IN PSYCHOLOGY

Vol. 5, No. 1, 2018, E-ISSN: 2312-1882 @ 2018 KWP

\section{Variables Selected}

Independent Variable: Yogic Exercises

Dependent Variables: flexibility, stamina (cardio-respiratory endurance) and Academic Achievement.

\section{Tools Used}

\section{$>$ AAHPERD technical manual for physical fitness variables.}

For assessing the physical fitness variables in terms of stamina (cardio-vascular endurance) and flexibility the AAHPERD, 1984 (American Alliance for Health and physical education, recreation and dance) technical manual for health related physical fitness test was used.

\section{$>$ Academic Achievement}

The total marks obtained by the students in their previous annual examination were used as the measure of academic achievement.

\section{$>$ Statistical Analysis of Data}

At the initial stage, the values of mean of all the variables were computed to see the difference of pre scores and post scores on each variable. At the second stage ANOVA was applied to know the significance of difference among group, gender, and between to test conditions i.e. pre-testing and post-testing.

\section{$>\quad$ Yogic Intervention}

Following yogic exercises were given to the experimental group for a period of three months.

Asanas:

Standing Postures:

Surya Namaskar with mantras.

(a) VRIKSHASANA

(b) TRIKONASANA

(c) TADASANA

Sitting Postures:
(a) SUKHASANA
(b) PADMASANA
(c) SIDDHASANA
(d) MANDUKASANA
(e) PASCHIMOTTANASANA
Lying Down Postures:
(a) BHUJANGASANA
(b) DHANURASANA
(c) SHALABHASANA
(d) SARVANGASANA
(e) SHAVASANA
(f) MAKARASANA
(g) DRADASANA

\section{Pranayama:}

(a) ANULOMA VILOMA 
INTERNATIONAL JOURNAL OF ACADEMIC RESEARCH IN PSYCHOLOGY

Vol. 5, No. 1, 2018, E-ISSN: 2312-1882 @ 2018 KWP
(b) NADISHODHANA
(c) BHASTRIKA
(d) BHRAMARI
(e) KAPALABHATI

Relaxation: Shavasana or Yog Nidra, Om recitation and Meditation.

\section{Results}

A repeated measure ANOVA $2 \times 2 \times(2)$ was computed for concentration and academic achievement for the groups viz. experimental group and control group and two sexes. The results of F-test are as follows:

\section{Flexibility}

\section{Group and Flexibility}

The F-ratio for the main effects of group viz. Experimental and Control group is $47.42 * * p<.01$ under error $A$. This indicates the significant mean difference with mean $(M=65.29)$ for experimental group and mean $(M=60.00)$ for control group. The results show the superiority of Experimental group over the Control group.

\section{Gender and Flexibility}

The F-ratio for the main effects of gender is $10.28 * * p<.01$ under error $A$ indicating the significant differences in the flexibility of boys and girls with mean value $(M=63.71$ for females) and mean $(M=61.57$ for males). The results show the better flexibility in females as compared to the males.

\section{Yoga and Flexibility}

The F-ratio for the effect of yoga on flexibility is $14.67^{* *} p<.01$ under error B indicating the positive and significant effect of yoga on the flexibility of students (males and females) in Experimental group at the post test $(M=65.59$ ) as compared to the Control (non-treatment) group at the post test ( $M=59.60)$.

\section{Interaction Effect of Group X Yoga on Flexibility}

It is significant at .05 level with F-ratio being 5.76* under error B which depicts that in the post-test group, the effect of yoga is highly pronounced in the Experimental group showing the significant difference between the Control and the Experimental group, whereas, the two groups are almost similar at the pre-test level i.e. the level of flexibility remains almost the same (see figure 1 and Table 1).

TABLE-1: Mean Contingency Table

\begin{tabular}{|l|l|l|}
\hline Test Conditions & Control & Experimental \\
\hline Pre-test & 59.22 & 59.99 \\
\hline Post-test & 60.79 & 70.60 \\
\hline
\end{tabular}


INTERNATIONAL JOURNAL OF ACADEMIC RESEARCH IN PSYCHOLOGY Vol. 5, No. 1, 2018, E-ISSN: 2312-1882 @ 2018 KWP

Fig.1: Flexibility in control and experimental group from pre to post test Flexibility in Group
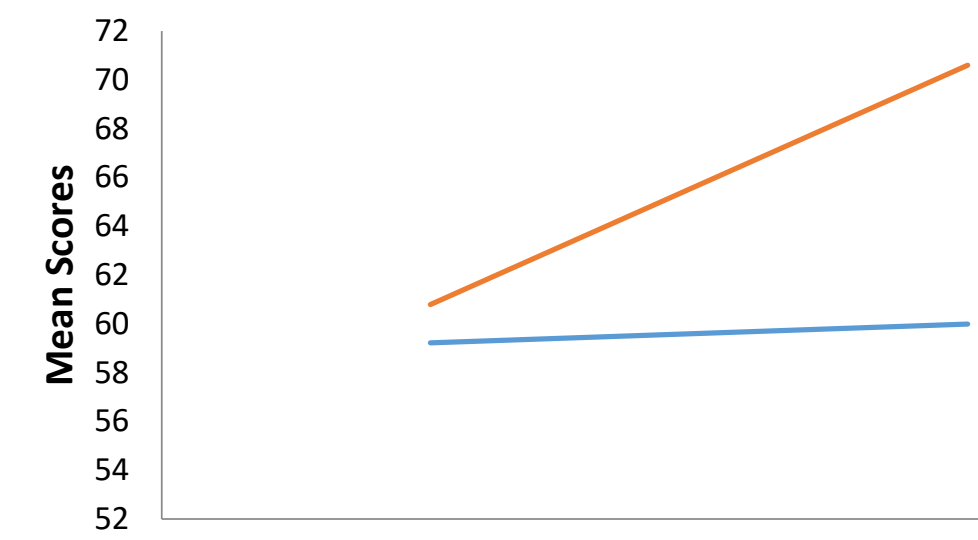

Pre-test

Post-test

56

54

52

Control

Experimental

Interaction Effect of Gender X Yoga on flexibility

Almost identical effect of Yoga could be seen in both the genders in terms of flexibility but the effect is more pronounced in the girls with F-ratio being $6.62 * *$ $\mathrm{p}<.01$ under error B. (See figure 2 along with Table-2).

TABLE- 2: Means Contingency Table

\begin{tabular}{|l|l|l|l|}
\hline Gender & Test Conditions & Control Group & Experimental Group \\
\hline Males & Pre-test & 58.46 & 59.24 \\
\cline { 2 - 4 } & Post-test & 59.22 & 69.38 \\
\hline Females & Pre-test & 59.98 & 60.74 \\
\cline { 2 - 4 } & Post-test & 62.36 & 71.82 \\
\hline
\end{tabular}


Fig. 2: Flexibility in Males and Females from Pre to Post-test.

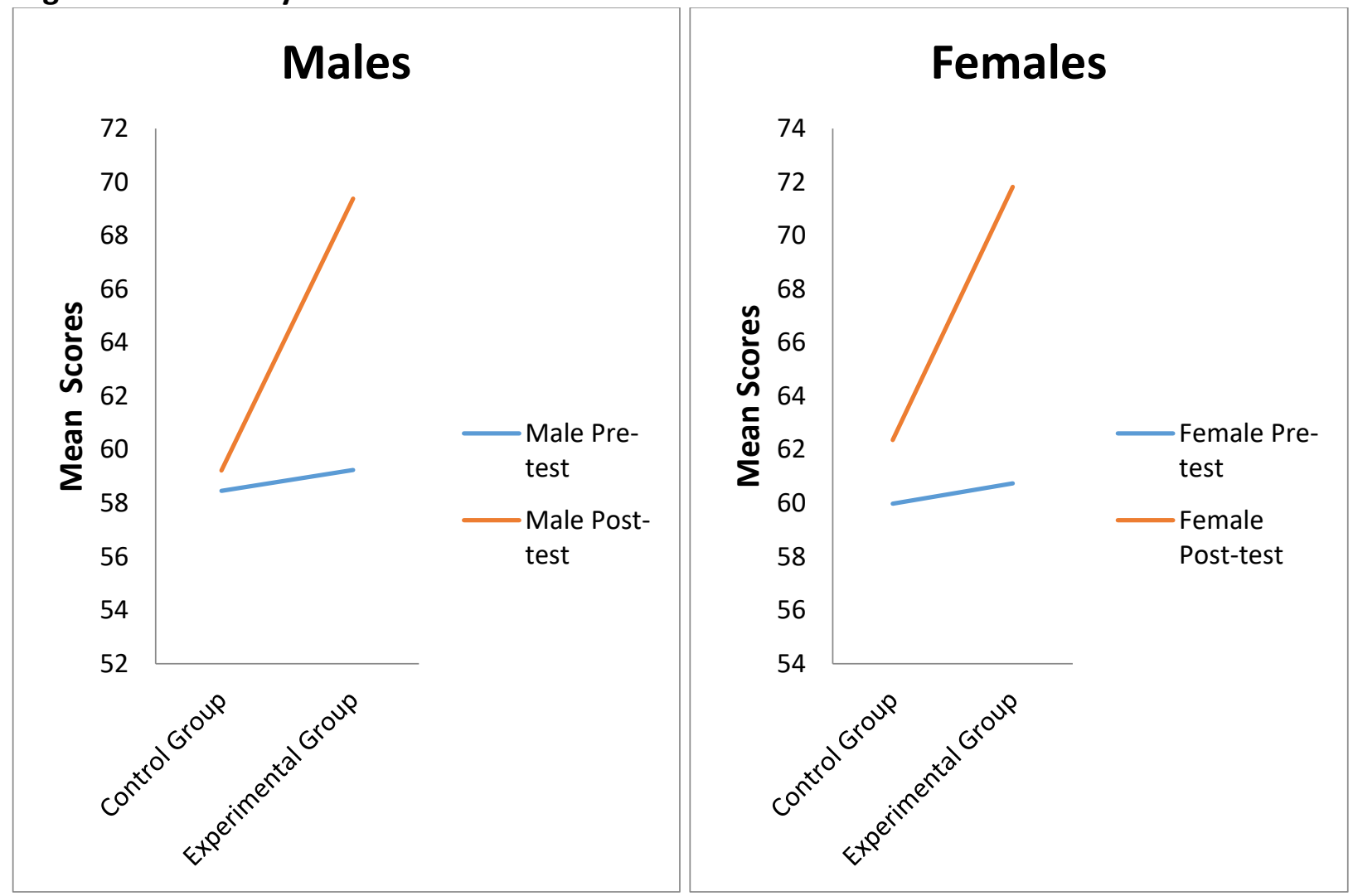

Stamina (Cardio-vascular Endurance)

\section{Group and Stamina}

The F-ratio for the main effect of group under error $A$ is $16.00 * *, p<.01$. This indicates a significant mean difference with mean value $(M=2.44)$ for the experimental group and $(M=2.47)$ for the control group.

\section{Gender and Stamina}

The main effect of gender is $148.00 \mathrm{p}<.01$ under error A. This indicates a significant gender differences

\section{Interaction effect of group $x$ gender on Stamina}

The $F$ ratio for the two factor interaction of group $x$ gender is 2.01 which is not significant.

\section{Intervention effect under error $B$.}

The F-ratio for the main effect of intervention i.e. yogic exercises is $9.84 \mathrm{p}<.01$ under error $B$. This indicates a positive and significant effect of intervention on stamina of student at the post-test $(M=2.32)$ as compared to the pre-test $(M=2.59)$. 
Inteaction Effect of Group $\times$ Intervention under Error B.

The $F$ - ratio for the interaction effect of group $x$ intervention is $9.56<.01$ under error $B$. This indicate a significant mean difference with mean value $(M=2.44)$ for the experimental group and $(M=2.47)$ for the control group.

\section{TABLE- 3: Group Means of Stamina}

\begin{tabular}{|l|l|l|}
\hline Test conditions & Control & Experimental \\
\hline Pre-test & 2.52 & 2.66 \\
\hline Post-test & 2.42 & 2.22 \\
\hline
\end{tabular}

Fig.3 Stamina in Group from Pre to Post-Test

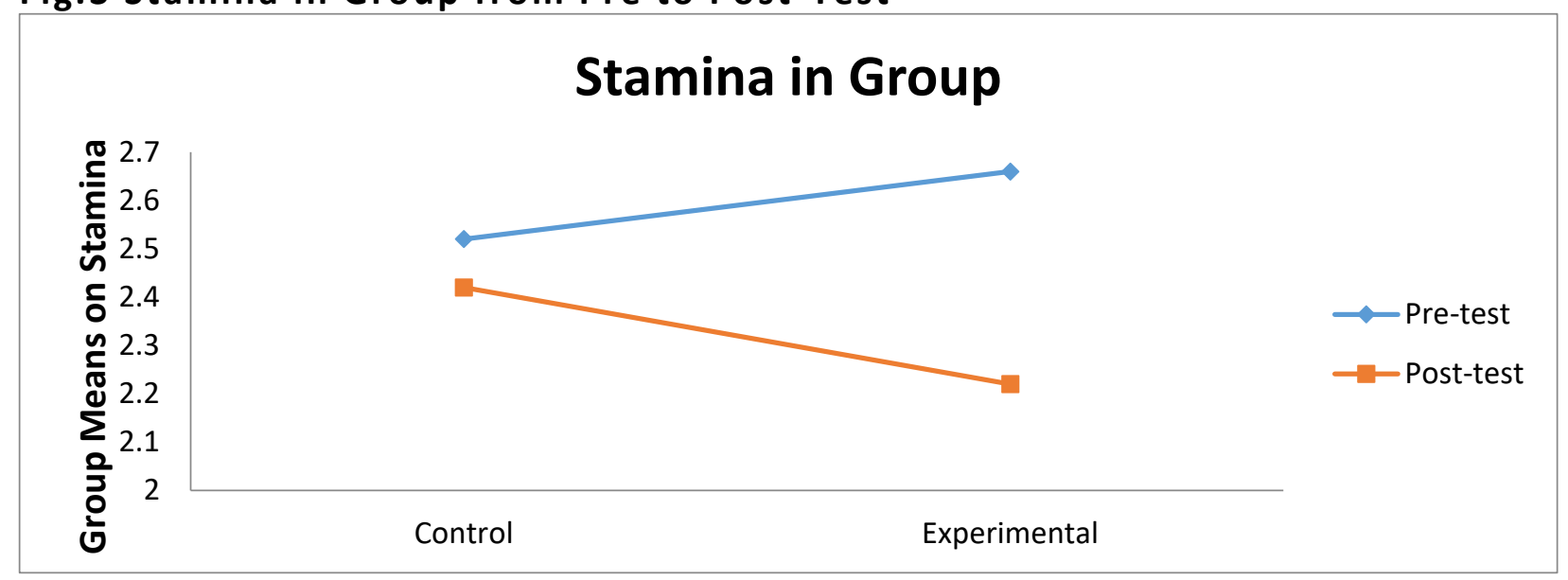

Interaction Effect of group $x$ gender $x$ intervention on Stamina.

The $F$ ratio for the interaction effect of group $x$ gender $x$ intervention on Stamina is $8.50 \mathrm{P}<.01$. This depicts that both boys and girls of the experimental group have gained significantly from the intervention programme but the boys have gained slightly more as compared to girls. 
INTERNATIONAL JOURNAL OF ACADEMIC RESEARCH IN PSYCHOLOGY

Vol. 5, No. 1, 2018, E-ISSN: 2312-1882 @ 2018 KWP

TABLE: 4

Means of group and gender in pre-and post-testing

\begin{tabular}{|l|l|l|l|}
\hline Gender & & Control Group & Experimental Group \\
\hline Males & Pre-test & 2.23 & 2.37 \\
\hline & Post-test & 2.13 & 1.91 \\
\hline Females & Pre-test & 2.82 & 2.96 \\
\hline & Post-test & 2.72 & 2.54 \\
\hline
\end{tabular}

Fig 4: Stamina of group and gender in pre and post-test conditions

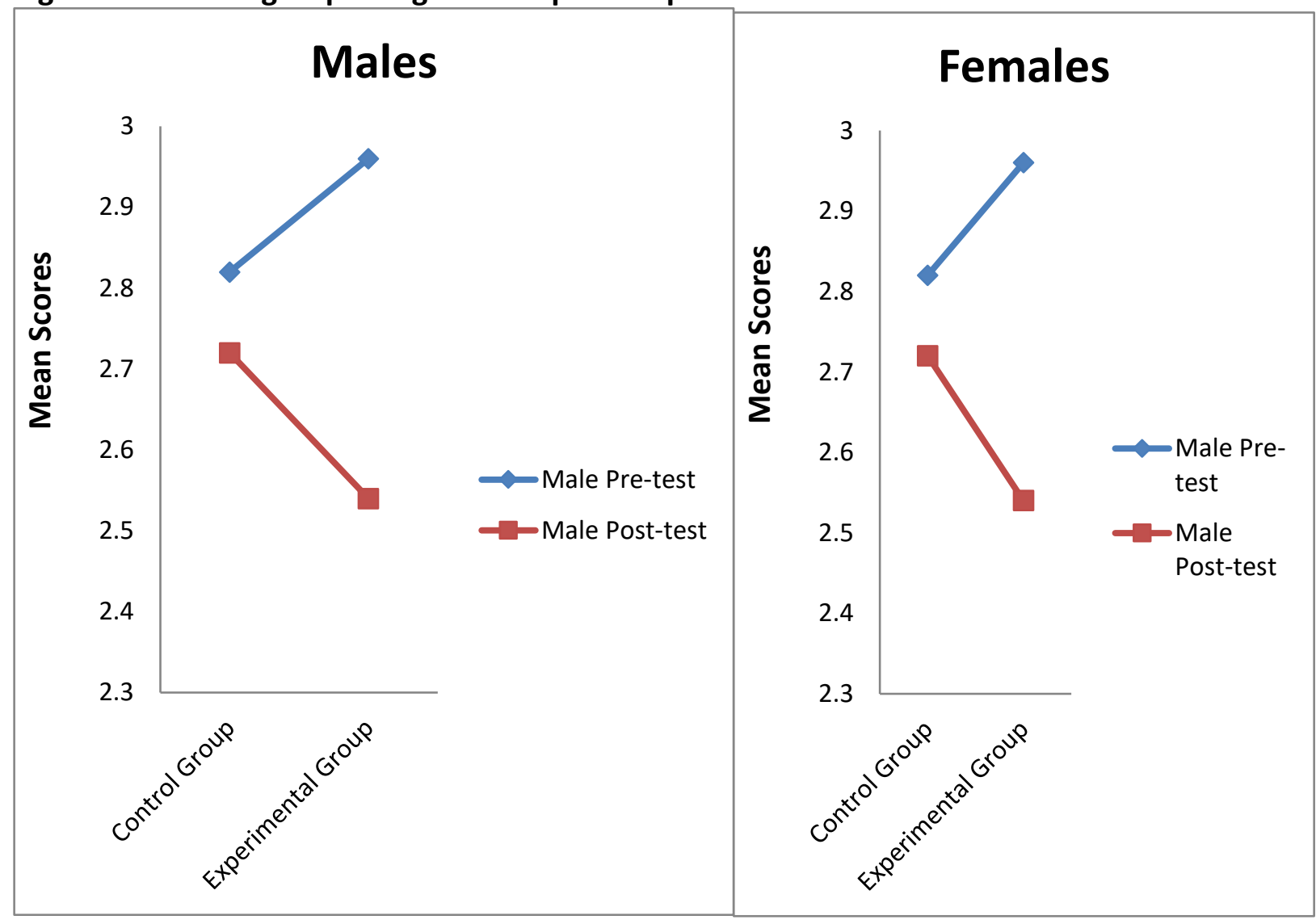

\section{Academic Achievement}

\section{Group \& Academic Achievement}

On this variable, ANOVA has yielded a significant F-ratio of $129.64 * *$ under error $A$, the main effect of group indicating the significant mean differences with Experimental group showing the superiority of mean ( $M=55.31$ ) over the Control group $(M=50.66)$ on academic achievement.

\section{Gender and Academic Achievement}

On this variable, ANOVA has again yielded a significant F-ratio of $9.32 * p<.05$ under error $A$ for gender, indicating the significant mean differences between the 
INTERNATIONAL JOURNAL OF ACADEMIC RESEARCH IN PSYCHOLOGY

Vol. 5, No. 1, 2018, E-ISSN: 2312-1882 @ 2018 KWP

sexes with females outperforming $(M=54.31)$ the males $(M=51.66)$ in their academic achievement.

\section{Yoga and Academic Achievement}

The F-ratio for the treatment i.e. yoga is $4.86^{* *} p<.01$ under error $B$ indicate that yoga has significant and positive effect on the academic achievement of the students in yogic i.e. intervention group (experimental group) at the post test with $M=55.93$ as compared to the non-treatment group control group with $M=50.04$ ).

\section{Interaction Effect of Group X Yoga on Academic Achievement}

Significant differences in academic achievement between Control and Experimental group at the post-test appear obviously due to the yogic intervention with F-ratio being $6.87^{* *} \mathrm{p}<.01$ under error B as compared to the pre-test where the level of academic achievement remains almost the same for both the groups. Thus, the curves clearly reveal that the effect of yoga is highly pronounced in the Experimental group as compared to the control group at the post-test (see figure 3 along with table 3 ).

TABLE- 5: Means Contingency Table

\begin{tabular}{|l|l|l|}
\hline Test conditions & Control & Experimental \\
\hline Pre-test & 50.17 & 49.92 \\
\hline Post-test & 51.16 & 60.70 \\
\hline
\end{tabular}

Fig. 5 Academic Achievement in Group

\section{Academic Achievement}

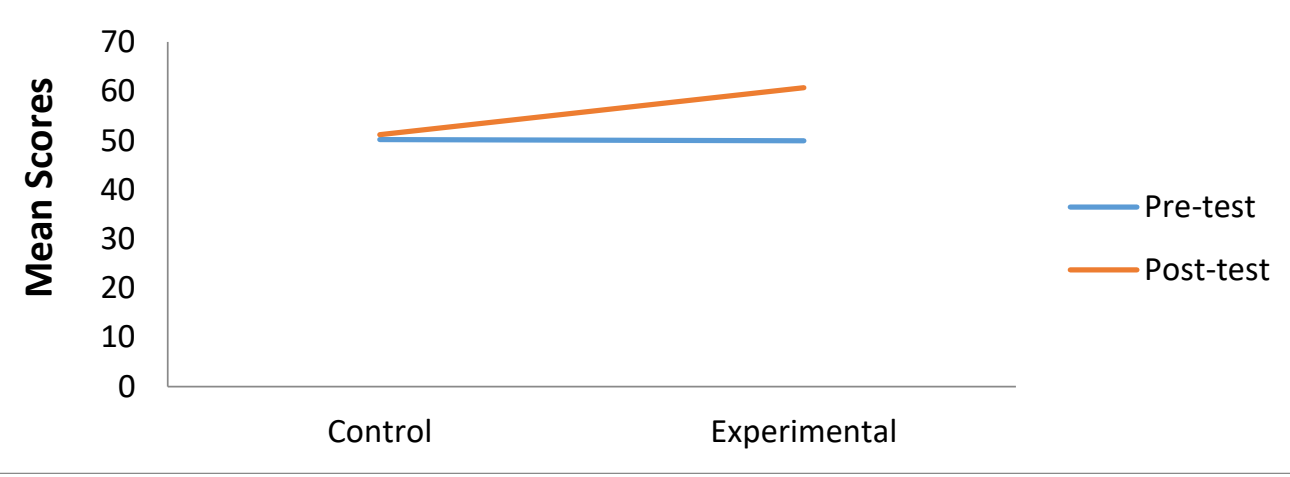

Interaction Effect of Gender X Yoga in Academic Achievement

The interaction reveals that both the genders are almost similar at the pretest but at the post-test level the yogic effect is more favorably pronounced in girls. 
INTERNATIONAL JOURNAL OF ACADEMIC RESEARCH IN PSYCHOLOGY

Vol. 5, No. 1, 2018, E-ISSN: 2312-1882 @ 2018 KWP

TABLE- 6: Means of Group and Gender in Pre-and Post-testing Conditions

\begin{tabular}{|l|l|l|l|}
\hline Gender & Test Conditions & Control Group & Experimental Group \\
\hline Males & Pre-test & 49.76 & 48.30 \\
\hline & Post-test & 49.90 & 59.70 \\
\hline Females & Pre-test & 52.28 & 51.54 \\
\hline & Post-test & 52.43 & 61.70 \\
\hline
\end{tabular}

Fig 6: Academic Achievement of Group and Gender from Pre to Post-Test

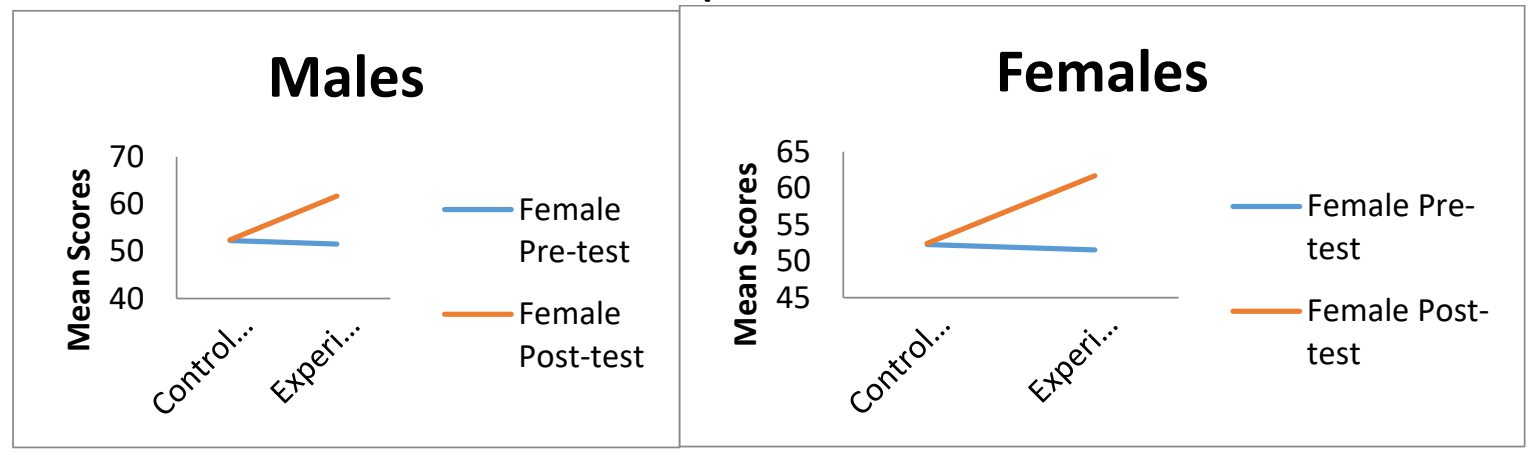

\section{Discussion of Results}

The present results concerning the variables of flexibility, stamina in terms of cardio-vascular endurance and academic achievement have been rationalized in terms of the hypotheses that experimental group will outperform the control group due to yogic interventions/exercises. These results could best be depicted through the two-way interaction effects of groups $x$ yoga and gender $x$ yoga on flexibility, stamina in terms of cardio-vascular endurance and academic achievement respectively.

On the variables of flexibility, stamina in terms of cardio-vascular endurance and academic achievement, the two way interactions between group $\mathrm{x}$ yoga have been found to be significant at .01 level under error B. See results section for F-ratios and can be confirmed through the curves (figure 1,3,5 \& 6 tables 1,3,5 \& 6). Both the interactions reveal that the Experimental group (treatment group) has been benefited more in terms of flexibility and stamina (by $20.18 \%$ ) and academic achievement (by $16.48 \%$ ) obviously due to the yogic treatment. Hence, the hypotheses stand confirmed the reason being that the effect is profound and tremendous. The rationale for the yogic treatment could be offered in the following manner. Yogic exercises attain steadiness of body and mind, a feeling of lightness, suppleness and psychophysical poise (Rama etal, 1976 and Harvey, 1988).

Advanced Asanas and Yoga postures evoke feelings of sublimity, inner tranquility, psychic strength and purity of consciousness. Selvamurthy (1986) observed that the regular practice of postures and breath control improved cognitive ability of the brain including concentration, memory and psychomotor performance. The scientific breathing (Pranayama) is extremely beneficial to lungs and the proper functioning of the blood as it brings oxygen and energy to every cell, cleans the organism and expels the toxins. Pranayama followed by selected Asanas further tones the muscles, 
helps in removing the disease, increases the elasticity of the body and lung tissues, purifier external and internal organs and maintains the highest standards of physical and mental efficiency by increasing the individual's mental power, happiness vigour and vitality. Just as the goldsmith removes the impurities of gold by heating it in the furnace and the blowpipe vigorously, so the impurities of body and mind can be removed by the practice of Pranayama e.g. Kapalabhati and Bhastrika remove the phlegm, cleans the nerve channels, purify the bloodstream, regenerates the liver, spleen and pancreas, warms the body and tones up the entire nervous system and Asanas stimulate and tone up the endocrine glands. The Asanas viz. Siddhasana, Swastikasana, Padmasana etc. increase the psychophysical energies by giving the body inner harmony, stimulating the nervous system, strengthening the muscles of the chest, spine and legs, improving the digestive system and also developing the stamina.

Dradasana and shavasana have been found to be the best exercises for relaxation and rest. They ward off fatigue, increase mental repose, improve immediate memory, tone up nervous system and are highly beneficial for those who suffer from headache of sleeplessness (Kulkarni, 2002). Bagga and Gandhi (1983) found that the practice of Shavasana increases galvanic skin resistance (GSR) significantly which is indicative of the deactivation of the SNS and a dominant PNS. Hence, yogic exercises bring about purity and balance in the functioning of sympathetic and parasympathetic activity.

Similarly, the 2 way interaction effect of gender $x$ yoga have also turned out to be significant at .01 level under error $B$ on the variables of concentration and academic achievement. (For details see results section and the interaction curves in figures $2 \& 4$ and tables 2 and 4) revealing the significant and positive effect of yoga in both the genders. The interaction curves further reveals that the effect of yoga is more favorably pronounced in the girls at the post-test with $14.2 \%$ and $10.42 \%$ of enhancement to that of boys who have shown $7.60 \%$ and $5.16 \%$ of enhancement in the level of flexibility, stamina and academic achievement.

Thus, the results have shown that both the sexes have shown improvement due to yogic exercises but the boys have been benefited more may be due to their bodily disposition and early socialization practices due to which they take any kind of task seriously and do not get easily distracted, rather remain focused (Sharma \& Malhotra, 2000) and hence make the best use of the yoga classes which get reflected in their enhanced concentration and academic achievement. Overall, there is a powerful effect of yoga irrespective of age, gender, caste or creed (Sharma \& Singh, 2014).

In a nutshell, it can be said that yoga alone offers a relaxed outlook in life. A rested mind and a rested body are the best kind of health insurance. It is from the rested mind that the entire beneficial cycle starts. In psychoanalytical language yoga helps us to conquer the neurotic personality of our times and makes the mind peaceful and happy. Chanting of OM stimulates the brain cells resulting in their reactivation and ultimately leading to better flexibility and stamina (Ghosh, S.K. 2003). It is rightly said that if you wish to change the society, first change yourself and through yoga man can find his zest for life. Yoga bestows on man healthier and happier life. Yogasanas give suppleness to the spine tree of our life by calming the tired nerves, relaxing the muscles, revitalizing the organs and nervous system thereby increasing the power of flexibility and cardiovascular endurance ultimately leading to achievement in any sphere. These exercises stimulates the brain cells resulting in their activation and ultimately leading to better concentration 
INTERNATIONAL JOURNAL OF ACADEMIC RESEARCH IN PSYCHOLOGY

Vol. 5, No. 1, 2018, E-ISSN: 2312-1882 @ 2018 KWP

\section{References}

Apte, U. S. (1965). The Practical Sanskrit Dictionary (Fourth Edition) Delhi, Motilal Banarsi Dass Publishers.

Bagga, O. P., \& Gandhi, A. (1983). A comparative study of the effect of the transcendental meditation and shavasana practice on cardiovascular system. Indian Heart Journal, 35(1), 39-45.

Brown, F. W., \& Holtzman, W. H. (1967). Scale for Survey of Study Habit and Attitudes. Copyright by the Psychological Corporation, New York.

Chatterjee, S. C., \& Datta, D. (1984). An Introduction to Indian Philosophy, Eighth reprint Edition, Calcutta. University of Calcutta.

Ghosh, S. K. (2003). Effects of physical exercises, yogic practices and their combined training on selected physiological variables among high school boys. Yoga-Mimamsa. 35(182), 15-25.

Harvay, J. R. (1988). Stress Exercise and Relaxation. The Quit Mind. Technique for Transorming Stress. Pennsylavania Himalayan International Institute.

lyengar, B. K. S. (2004). The Path to Holistic Health. A Dorling Kindersley Book London, 21-32.

James, A. (2002). Psycho-physiological effect of Hatha Yoga on Musculoskeletal and Cardiopulmonary Function. A literature review. The Journal of Alternative and Complimentary Medicine, 8(6), 797-812.

Kulkarni, D. D. (2002). Effect of Shavasana on Resource conservation and Stimulus Evaluation. YogaMimamsa. A Quarterely Journal, 34 (3 \&4), 214-223.

Radhakrisnan, S., Moore, C. A. (1967). A Source Book in Indian Philosophy, Princeton. ISBN 069101958.

Rama, S., Ballentine, R., \& Ajay, S. (1976). Yoga and Psychotherapy. The Evolutions of Consciousness. Honesdable. The Himalayan Institute.

Selvamurthy, W. (1986). Yoga for Everyone- a physiologists' view. Journal of Oriental Research, 63 (7), 7-32.

Sharma, A., \& Malhotra, D. K. (2007). Personality and Social Norms. Concept Publications, New Delhi.

Sharma, A., \& Singh, R. (2014). Educational Stress in Adolescents: Chanting Mantras as a Powerful Coping Strategy. Global Journal of Human-Social Science: A Arts \& Humanities - Psychology, 14(1), 30-51. 